\title{
Nanostructured Carbon Electrocatalyst Supports for Intermediate-Temperature Fuel Cells: Single-Walled Versus Multi-Walled Structures
}

\author{
Alexander B. Papandrew ${ }^{\mathrm{a}, *}$, Ramez A. Elgammal ${ }^{\mathrm{a}}$, Mengkun Tian ${ }^{\mathrm{a}}$, Wesley D. \\ Tennyson $^{\mathrm{b}}$, Christopher M. Rouleau ${ }^{\mathrm{c}}$, Alexander A. Puretzkyc ${ }^{\mathrm{c}}$, Gabriel M. \\ Veith $^{\mathrm{b}}$, David B. Geohegan ${ }^{\mathrm{c}}$, Thomas A. Zawodzinski, Jr ${ }^{\mathrm{a}, \mathrm{b}}$ \\ ${ }^{a}$ Department of Chemical and Biomolecular Engineering, University of Tennessee, \\ Knoxville, Tennessee 37996 USA \\ ${ }^{b}$ Materials Science and Technology Division, Oak Ridge National Laboratory, Oak Ridge, \\ TN 37831 USA \\ ${ }^{c}$ Center for Nanophase Materials Sciences, Oak Ridge National Laboratory, Oak Ridge, \\ TN, 37831 USA
}

\begin{abstract}
It is unknown if nanostructured carbons possess the requisite electrochemical stability to be used as catalyst supports in the cathode of intermediatetemperature solid acid fuel cells (SAFCs) based on the $\mathrm{CsH}_{2} \mathrm{PO}_{4}$ electrolyte. To investigate this application, single-walled carbon nanohorns (SWNHs) and multi-walled carbon nanotubes (MWNTs) were used as supports for Pt catalysts in SAFCs operating at $250{ }^{\circ} \mathrm{C}$. SWNH-based cathodes display greater maximum activity than their MWNT-based counterparts at a cell voltage of 0.8 $\mathrm{V}$, but are unstable in the SAFC cathode as a consequence of electrochemical carbon corrosion. MWNT-based cells are resistant to this effect and capable of operation for at least 160 hours at $0.6 \mathrm{~V}$ and $250{ }^{\circ} \mathrm{C}$. Cells fabricated with nanostructured carbon supports are more active $\left(52 \mathrm{~mA} \mathrm{~cm}^{-1}\right.$ vs. $28 \mathrm{~mA} \mathrm{~cm}^{-1}$ at $0.8 \mathrm{~V}$ ) than state-of-the-art carbon-free formulations while simultaneously displaying enhanced Pt utilization $\left(40 \mathrm{~mA} \mathrm{mg}_{\mathrm{Pt}}^{-1}\right.$ vs. $16 \mathrm{~mA} \mathrm{mg}_{\mathrm{Pt}}^{-1}$ at $\left.0.8 \mathrm{~V}\right)$. These results suggest that MWNTs are a viable support material for developing stable, high-performance, low-cost air electrodes for solid-state electrochemical
\end{abstract}

\footnotetext{
*Corresponding author. email: apapandrew@utk.edu phone:(865) 974-2421 fax: (865)
} 974-7076

Preprint submitted to Journal of Power Sources

October 23, 2016

(C) 2016. This manuscript version is made available under the Elsevier user license http://www.elsevier.com/open-access/userlicense/1.0/ 
devices operating above $230{ }^{\circ} \mathrm{C}$.

Keywords: $\mathrm{CsH}_{2} \mathrm{PO}_{4}$, carbon nanotubes, carbon nanohorns, fuel cells

\section{1. Introduction}

6

Fuel cells based on the crystalline solid acid proton conductor $\mathrm{CsH}_{2} \mathrm{PO}_{4}[1]$ (CDP), hereafter termed solid acid fuel cells[2, 3] (SAFCs) are a relatively new class of devices with the potential for adoption in stationary applications. SAFCs operate at approximately $250^{\circ} \mathrm{C}$, an intermediate temperature regime that eliminates the need for management of liquid reaction products or liquid electrolytes, while preserving access to a conventional materials set for components. Intermediate-temperature operation also confers an excellent resistance to poisoning on $\mathrm{Pt}[3], \mathrm{Pd}[4]$, and $\mathrm{Ru}[5]$ anode catalysts, permitting the use of minimally processed reformed hydrocarbon fuels.

In contrast with the robust attributes of the anode, the current state of the cathode limits the potential reach of SAFCs. SAFCs are entirely solid state systems and do not benefit from either an oxygen-permeable ionomer or the presence of liquid water, attributes conducive to high catalyst utilization in lowtemperature polymer-based systems. A low active surface area in CDP-based systems impacts cathode performance strongly $[1,3]$. In response to this problem, the state-of-the-art SAFC cathode is based on a macroporous framework of the CDP electrolyte conformally coated by a network of Pt nanoparticles that serves as both the oxygen reduction catalyst and the electronic conductor [6, 7], to maximize catalyst-electrolyte interfacial area. This architecture is limited by the critical quantity of $\mathrm{Pt}$ required to maintain a percolating electronic conduction network in the electrode, resulting in undesirably high Pt loadings $(>1.5$ $\left.\operatorname{mg}_{P t} \mathrm{~cm}^{-2}\right)[6]$.

Implementation of durable electronically-conductive additives may be a pathway to lowering SAFC cathode Pt loadings to competitive levels. This is certainly the dominant approach in low-temperature polymer systems and the intermediate-temperature phosphoric acid system, both of which rely on car- 
bon as a catalyst support[8]. These systems have typically used turbostratically disordered carbons found on the continuum between completely amorphous carbon black and perfectly ordered graphite, balancing the high surface area and porosity of the former with the electrochemical stability of the latter.

Electrochemical stability is a critical parameter in a fuel cell electrode, as carbon can itself react with water (a reaction product), either forming surface oxide species or carbon dioxide according to the carbon corrosion $[9,10,11,12$, $13,14,15,16,17,18,19]$ reaction

$$
\mathrm{C}+2 \mathrm{H}_{2} \mathrm{O} \rightarrow \mathrm{CO}_{2}+4 \mathrm{H}^{+}+4 \mathrm{e}^{-}
$$

resulting in degradation of the electrode as carbon is lost in the gas phase.

Nanostructured carbons have been examined for some time as potential substituents in fuel cell electrodes due in part to their ability to resist this process of carbon corrosion. Substantial progress has been made in implementing metallic catalysts supported on multiwalled carbon nanotubes[20, 21, 22, 23, 24, 25], single-walled carbon nanotubes[21, 22, 24, 26, 25], and single-walled carbon nanohorns $[21,25,27,28,29,30]$ in low-temperature acidic enviroments and in the intermediate-temperature phosphoric acid systems.

Previous work focused on implementing nanostructured carbon in SAFCs demonstrated novel architechtures[31, 32, 33] with ultra-low Pt loadings applied to the $\mathrm{H}_{2} / \mathrm{H}^{+}$redox couple at the anode. It remains an open question if carbon is a viable support material at the higher electrochemical potentials of the cathode. In this contribution, we address that question, investigating the use of both single-walled and multi-walled carbon nanostructures, in the form of nanohorns (SWNHs) and nanotubes (MWNTs), respectively, as catalyst supports in the SAFC cathode.

\section{Experimental Methods}

\subsection{Materials Preparation}

SWNHs were prepared via a laser vaporization procedure very similar to that described previously $[34,35,36]$. Carbon targets were prepared from a 
graphite adhesive (BC628, Bay Composites). The adhesive was initially baked in a closed vessel at $120^{\circ} \mathrm{C}$ for 4 hours. The resulting target was then annealed at $800{ }^{\circ} \mathrm{C}$ under flowing Ar for 4 hours to remove any residual solvents. Pulsed laser vaporization $(\mathrm{PLV})$ of the SWNHs was completed in a quartz tube reactor at $1100{ }^{\circ} \mathrm{C}$ in 735 torr and $2 \mathrm{~L} \min ^{-1}$ of Ar flow. A Nd:YAG $(\lambda=1.064 \mu \mathrm{m})$ laser with typical pulse power of $420 \mathrm{~W}$ was used to ablate the targets and the resulting products were collected in a HEPA-filtered collection chamber.

Commercial MWNTs (Cheaptubes) were used as received.

Pt catalysts supported on SWNHs and MWNTs were synthesized from $\mathrm{Pt}(\mathrm{II})$-pentanedionate precursor (Strem) in a fixed bed at $210{ }^{\circ} \mathrm{C}$ under a reduced pressure $\mathrm{N}_{2}-\mathrm{H}_{2} \mathrm{O}$ atmosphere. In this procedure the solid Pt precursor is intermixed with the solid support and heated slowly in a deoxygenated atmosphere, causing sublimation, adsorption, and finally decomposition of the precursor to zero-valent $\mathrm{Pt}$. This route is similar to other supported metallic catalyst syntheses that we have $\operatorname{reported}[4,7,6,37,5]$.

\subsection{Materials Characterization}

Pristine and post-test $60 \mathrm{wt} \% \mathrm{Pt} / \mathrm{SWNH}$ and $60 \mathrm{wt} \% \mathrm{Pt} / \mathrm{MWNT}$ were characterized by high-resolution transmission electron microcopy (HRTEM) imaging in a Zeiss Libra $200 \mathrm{MC}$ TEM at an acceleration voltage of $200 \mathrm{kV}$. The information limit of HRTEM images in this microscope is $\sim 0.1 \mathrm{~nm}$. Imaging of SAFC cathodes in cross-section was performed with a Zeiss Auriga 40 SEM at an accelerating voltage of $3 \mathrm{kV}$ using the in-lens detector with a resolution of approximately $2-3 \mathrm{~nm}$.

Powder X-ray diffraction patterns were recorded with a Bruker D2 Phaser diffractometer with Ni-filtered $\mathrm{Cu} \mathrm{K} \alpha$ radiation $(\lambda=0.15418 \mathrm{~nm})$. Raman spectra were recorded by a Renishaw 1000 confocal microRaman spectrometer with an excitation wavelength of $532 \mathrm{~nm}$ under a $50 \times$ objective and $10 \%$ laser power. 


\subsection{Cell Fabrication}

Solid acid fuel cells were fabricated using an anode-supported configuration similar to those described previously $[3,6,7]$. Using a bilayer sintered stainless steel (grade 304$)$ mesh disc $\left(2.85 \mathrm{~cm}^{2}\right)$ as an anode current collector and structural support, anode, membrane, and cathode layers were sequentially formed by uniaxal compression of powdered composites in a stainless steel die. Anodes were formed at $\sim 90 \mathrm{MPa}$ from a mechanical mixture of CDP, $60 \mathrm{wt} \% \mathrm{Pt}$ supported on carbon black (Vulcan XC-72R, Cabot Corp.) and naphthalene (a fugitive binder) in a 3:1:1 ratio, respectively, by weight. The CDP membrane was applied to the anode at $125 \mathrm{MPa}$ and was approximately $50 \mu \mathrm{m}$ in thickness. Experimental cathodes comprised of $25 \mathrm{mg}$ of a $3: 1$ by weight mixture of CDP and 60wt\%Pt supported on either MWNTs or SWNHs were applied to the dense CDP membrane at a pressure of $30 \mathrm{MPa}$. The areal Pt loading of the experimental cathodes was $1.3 \mathrm{mg}_{\mathrm{Pt}} \mathrm{cm}^{-2}$, and each contained $0.88 \mathrm{mg}$ of carbon per $\mathrm{cm}^{-2}$. State-of-the art cathodes were comprised of $25 \mathrm{mg}$ of $20 \mathrm{wt} \%$ Pt supported on fine CDP[6] laminated at $30 \mathrm{MPa}$ with a Pt loading of 1.75 $\mathrm{mg}_{\mathrm{Pt}} \mathrm{cm}^{-2}$. Cathode current collectors were coarse single-layer stainless steel (grade 316) mesh and a carbon paper interlayer (SGL 34AA).

\subsection{Electrochemical Testing}

Fuel cell testing was conducted using stainless steel test rigs at a temperature of $250{ }^{\circ} \mathrm{C}$ with gases hydrated to a dew point of $75{ }^{\circ} \mathrm{C}$ (approximately 0.35 bar water partial pressure). Anodes were supplied ultrahigh-purity $\mathrm{H}_{2}$ at a flow rate of $30 \mathrm{sccm}$ and cathodes were supplied compressed air flowing at 70 sccm, provided by a centralized compressor. No back pressure was applied to either fuel or oxidant exhaust streams. Polarization curves were recorded with a Bio-Logic VSP potentiostat by scanning the working electrode potential at $10 \mathrm{mV} \mathrm{s}^{-1}$ from the open circuit potential to a cell potential of $0 \mathrm{~V}$. Each cell was subjected to a multi-step cyclic testing protocol consisting of 1.) a 10second relaxation to the open circuit voltage 2.) recording of a potentiostatic electrochemical impedance spectroscopy (EIS) spectrum from $200 \mathrm{kHz}$ to 200 
$\mathrm{mHz}$ at $0.8 \mathrm{~V}$ cell voltage with single sine perturbation amplitude of $10 \mathrm{mV} 3$.) recording of the polarization curve 4.) EIS spectrum 5.) 30 minute potentiostatic hold at $0.6 \mathrm{~V}$, followed by a repetition of this protocol. After 30 cycles the cells were held at $0.6 \mathrm{~V}$. The high-frequency intercept of the EIS spectrum was used to eliminate the ohmic resistance of the cell from the polarization curves, yielding what we refer to as iR-free polarization curves. Multiple cells were constructed for each electrode formulation, and plots of iR-free polarization curves (Figure 5b), HFR, and current density at $0.6 \mathrm{~V}$ (Figure 6) are averaged across these cells.

Corrosion testing was performed a temperature of $250{ }^{\circ} \mathrm{C}$ with gases hydrated to a dew point of $75^{\circ} \mathrm{C}$. Anodes were supplied ultrahigh-purity $\mathrm{H}_{2}$ and cathodes were supplied ultrahigh-purity $\mathrm{N}_{2}$. Corrosion currents were acquired via chronoamperometry at $1.0 \mathrm{~V}$ cell potential for $1800 \mathrm{~s}$.

\section{Results and Discussion}

Platinum nanoparticles (60 wt\%) were deposited on single-walled carbon nanohorns (SWNH) and multiwalled carbon nanotubes (MWNT) using a vapor deposition procedure[4, 5, 6, 7, 37]. High-resolution transmission electron microscopy (HRTEM) images of the SWNHs (see Supplementary Information) reveal a structure consisting of individual cone-shaped nanohorns with walls consisting of a single graphene layer and diameters of approximately $2 \mathrm{~nm}$ and lengths of approximately $10 \mathrm{~nm}$, clustered into a secondary dahlia-like aggregate structure. HRTEM images of pristine MWNTs show structures 10-20 nm in diameter with walls comprised of 10-20 graphene layers, closed ends, and internal herringbone nanostructure. MWNTs also contained approximately $1 \mathrm{wt} \%$ encapsulated Co remnant from CVD synthesis.

The XRD profile of as-synthesized SWNHs (Figure 1a) reveals two sharp diffraction peaks as well as broader features. We note a sharp peak at $26.4^{\circ}$ corresponding to the graphitic (002) plane[38], in addition to a peak at $25.9^{\circ}$ which may be attributed to diffraction from adjacent SWNH walls. An asymmetric 

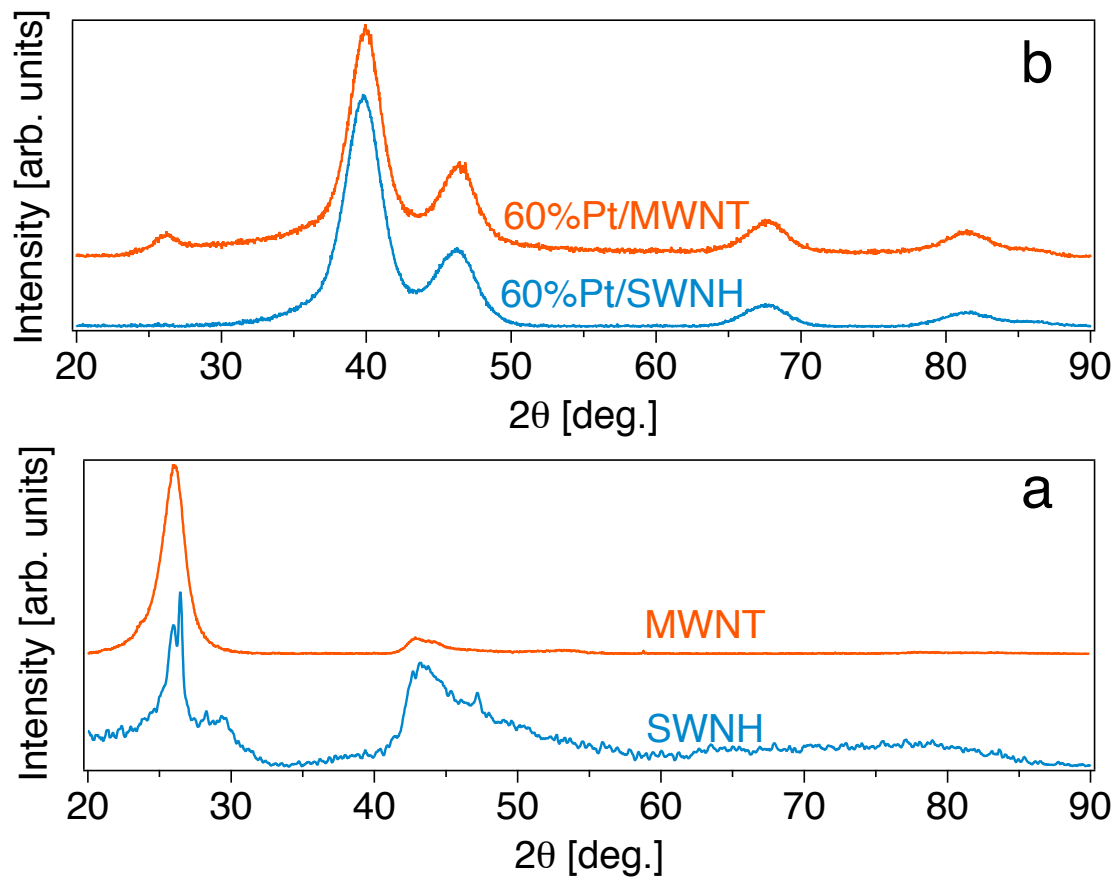

Figure 1: $\mathrm{Cu} \mathrm{K} \alpha$ x-ray diffraction patterns for pristine carbon supports and supports decorated with 60 wt\% Pt.

diffraction peak observed at $2 \theta \sim 43.3^{\circ}$ is assigned to the (100) reflection[39, 38].

The breadth and asymmetry of this peak originate from a lack of long-range correlations apart from those within the two-dimensional graphene sheets comprising the SWNH walls. XRD analysis of the as-received MWNTs is consistent with typically observed MWNT diffraction patterns, including a characteristically strong (002) graphite peak.

HRTEM (Figure 2) images of the Pt-decorated composites show Pt particles with adequate dispersion in a range from 3-5 $\mathrm{nm}$ in diameter, with mean particle sizes of $3.6 \mathrm{~nm}$ for $60 \mathrm{wt} \% \mathrm{Pt} / \mathrm{SWNH}$ and $3.3 \mathrm{~nm}$ for $60 \mathrm{wt} \% \mathrm{Pt} / \mathrm{MWNT}$. This is in agreement with Scherrer analysis of x-ray diffraction patterns (Figure 1b) which returns coherence lengths of $2.8 \mathrm{~nm}$ for $60 \mathrm{wt} \% \mathrm{Pt} / \mathrm{SWNH}$ and $3.2 \mathrm{~nm}$ for $60 \mathrm{wt} \% \mathrm{Pt} / \mathrm{MWNT}$. No Pt particles were judged to be on the interior surfaces of the supports based on TEM observation. 

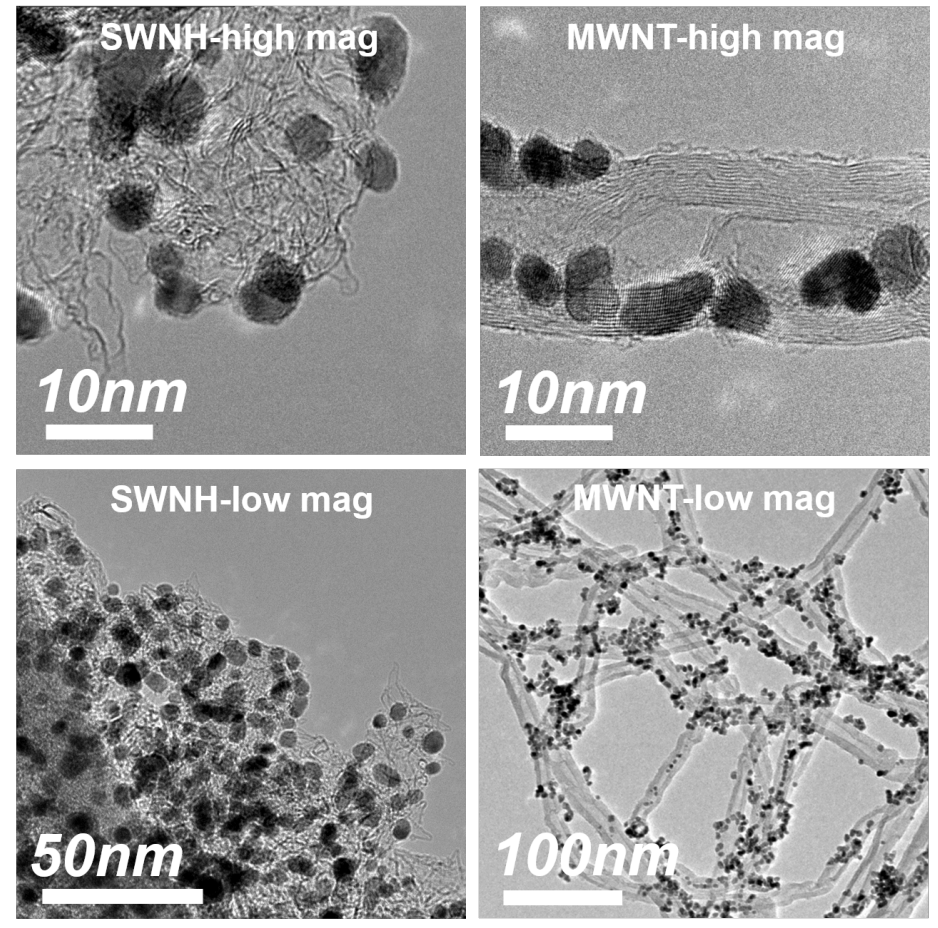

Figure 2: (HRTEM images of $60 \mathrm{wt} \% \mathrm{Pt}$ on SWNHs (left panels) and on MWNTs (right panels).

Raman scattering measurements of as-synthesized SWNHs (Figure 3 are consistent with other reports[36, 40]. Using the ratio of D-band $\left(\sim 1350 \mathrm{~cm}^{-1}\right)$ to G-band $\left(\sim 1600 \mathrm{~cm}^{-1}\right)$ intensity as a measure of structural disorder, we find a ratio slightly greater than 1 for the SWNHs and 0.75 for MWNTs, indicating greater defect density in the SWNH sample. We observe a slight blue shift of the SWNH G-band upon Pt deposition (approximately $8 \mathrm{~cm}^{-1}$ ), possibly attributable to decreased electron density in the $\mathrm{C}=\mathrm{C}$ bonds[41]. This effect is not present in the case of $60 \mathrm{wt} \% \mathrm{Pt} / \mathrm{MWNT}$. However in both cases we note a slight decrease in the intensity of the G' band, a senstive indicator of longrange order[42] that unsurprisingly is disrupted by introduction of a high metal loading of $\mathrm{Pt}$ in via chemical vapor treatment.

SAFC cathodes $\left(1.3 \mathrm{mg}_{\mathrm{Pt}} \mathrm{cm}^{-2}\right)$ formed from 3:1 (by weight) mixtures of the 


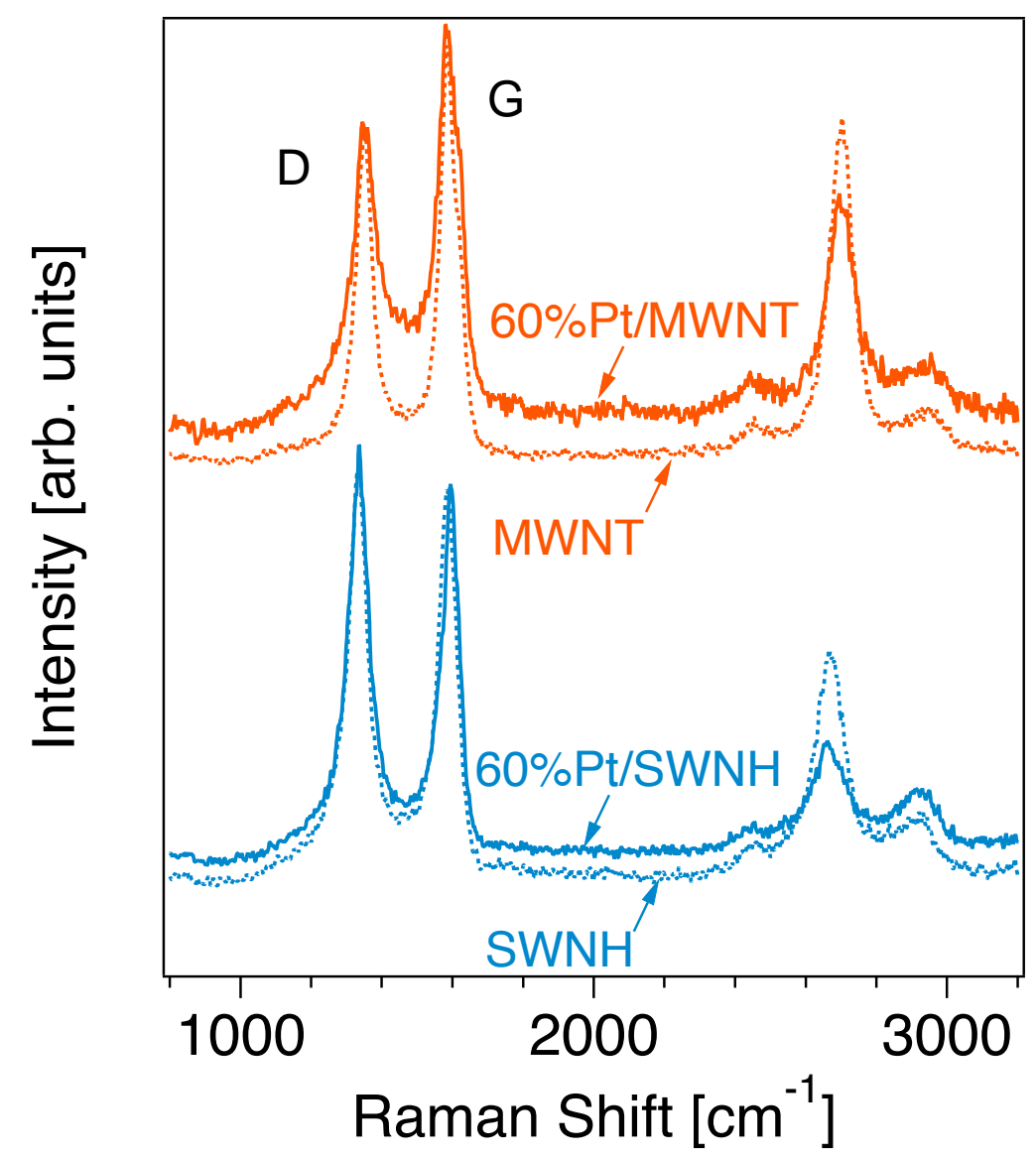

Figure 3: Raman spectra for pristine carbon supports and supports decorated with $60 \mathrm{wt} \%$ Pt.

$60 \mathrm{wt} \% \mathrm{Pt} / \mathrm{C}$ and CDP are shown in Figure 4. The cathode based on SWNHs is approximately $35 \mu \mathrm{m}$ in thickness while the MWNT-based cathode is slightly thicker, $\sim 45 \mu \mathrm{m}$. We note also that the SWNH sample appears to be qualitatively more homogeneous than the MWNT sample.

Fuel cell polarization curves for the experimental electrodes are shown in Figure 5. We note a substantially higher open circuit voltage (OCV) in the case of the MWNT electrode in comparison with the SWNH electrode $(0.97 \mathrm{~V}$ vs. $0.93 \mathrm{~V}$, respectively), which we attribute to a mixed potential arising from the 

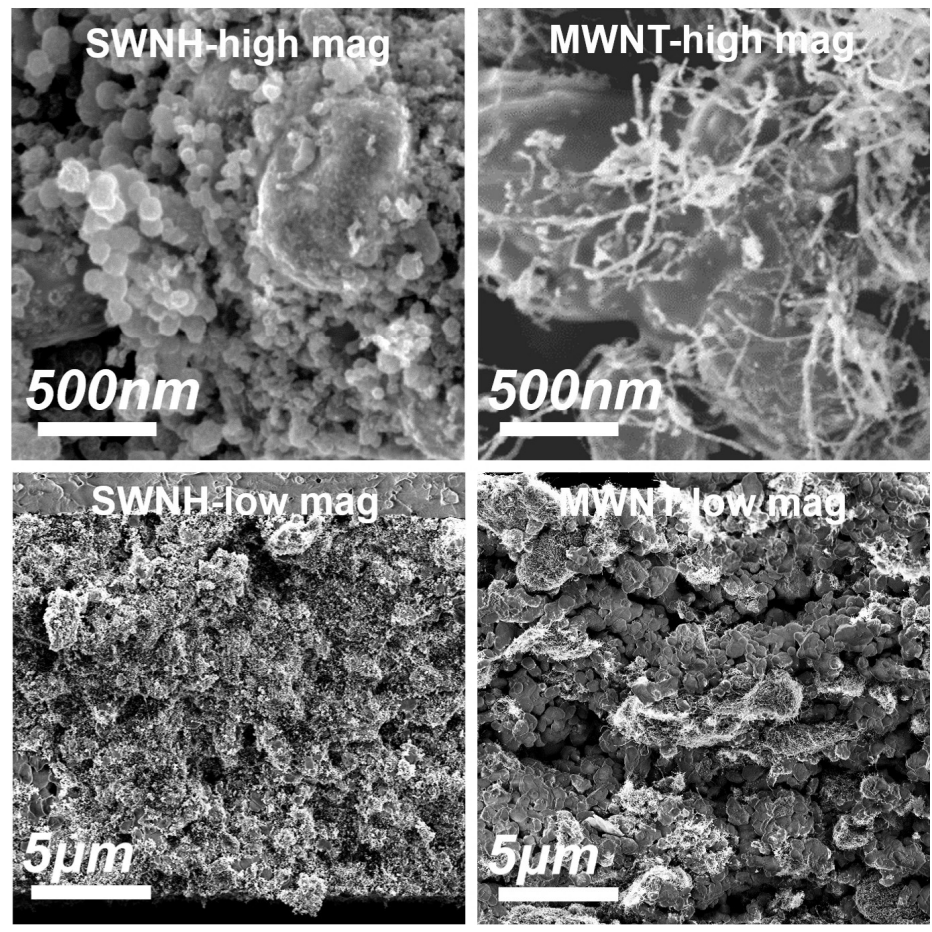

Figure 4: FESEM micrographs of as-fabricated SWNH-based (left panels) and MWNT-based (right panels) SAFC electrodes.

carbon corrosion reaction (Equation 1) investigated in more depth below. At an arbitrary voltage of $0.8 \mathrm{~V}$ (selected to be representative of electrode kinetics) the SWNH electrode is approximately $15 \%$ more active than the MWNT electrode. At the higher currents, the MWNT cell maintains a higher voltage, a consequence of its relatively lower ohmic resistance $\left(0.27 \Omega \mathrm{cm}^{2}\right.$ for the MWNT cell vs. $0.35 \Omega \mathrm{cm}^{2}$ for the SWNH cell). The consequences of this disparity are also evident in the iR-free representation (Figure $5 \mathrm{~b}$ ), whereupon removal of the ohmic contribution the activity of the SWNH cell is very close to that of the MWNT cell across the entire current range. The lower resistance of the MWNT cell results in a $21 \%$ increase in maximum power density with respect to the SWNH cell $\left(246 \mathrm{~mW} \mathrm{~cm}^{-2}\right.$ versus $202 \mathrm{~mW} \mathrm{~cm}^{-2}$, respectively; see Supplementary Information). These initial differences in ohmic resistance could 


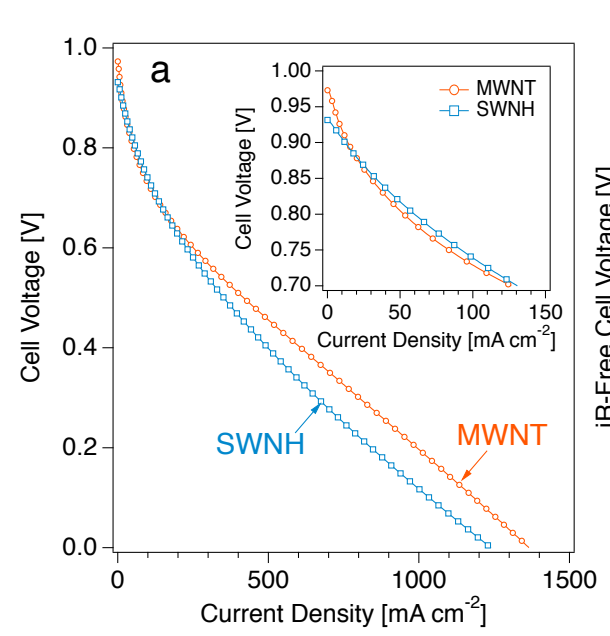
more detail below.

originate from the incipient effects of carbon corrosion, which we investigate in

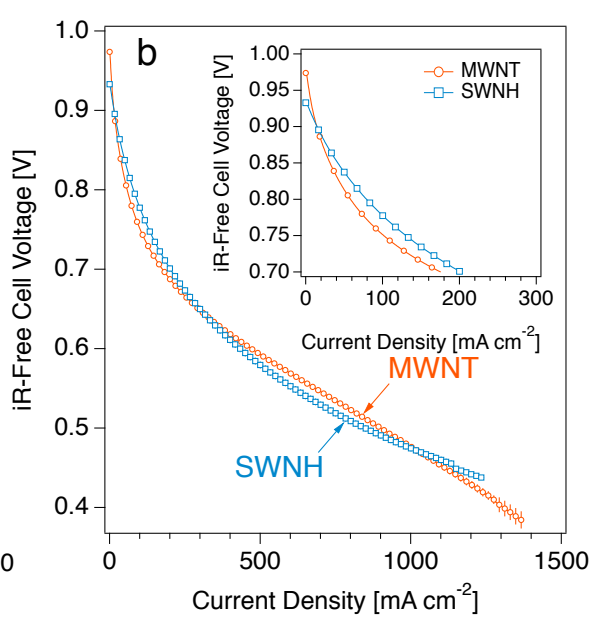

Figure 5: (a) Uncorrected and (b) average iR-free SAFC polarization curves recorded at 250 ${ }^{\circ} \mathrm{C}$ with $\mathrm{H}_{2}$ /air at $75{ }^{\circ} \mathrm{C}$ dew point for SWNH-based or MWNT-based cathodes. Insets show enlargement of the kinetic region.

Also clear in the iR-free data of Figure 5b is a deviation of the two corrected polarization curves at the extreme end of the current range. The MWNT cell displays a signature of mass-transport limited behavior in the negative convexity of the iR-free polarization curve at high current, while this is absent in the case of the SWNH cell. This may be a consequence of differences in the mixing of the electrolyte with the electrocatalyst, as we observed via SEM (Figure 4). The reduced thickness of the SWNH cathode could also result in more facile transport, though more detailed studies of reactant transport are required to validate this speculation.

We observed substantial and disparate changes in the polarization curves of the single-walled and multi-walled supports over the course of 20 hours of cyclic testing (Figure 6). Two effects are clear: a gradual increase in the performance of the MWNT cell, and a brief increase followed by a precipitous decline in the performance of the SWNH cell that is correlated with a large increase in its 

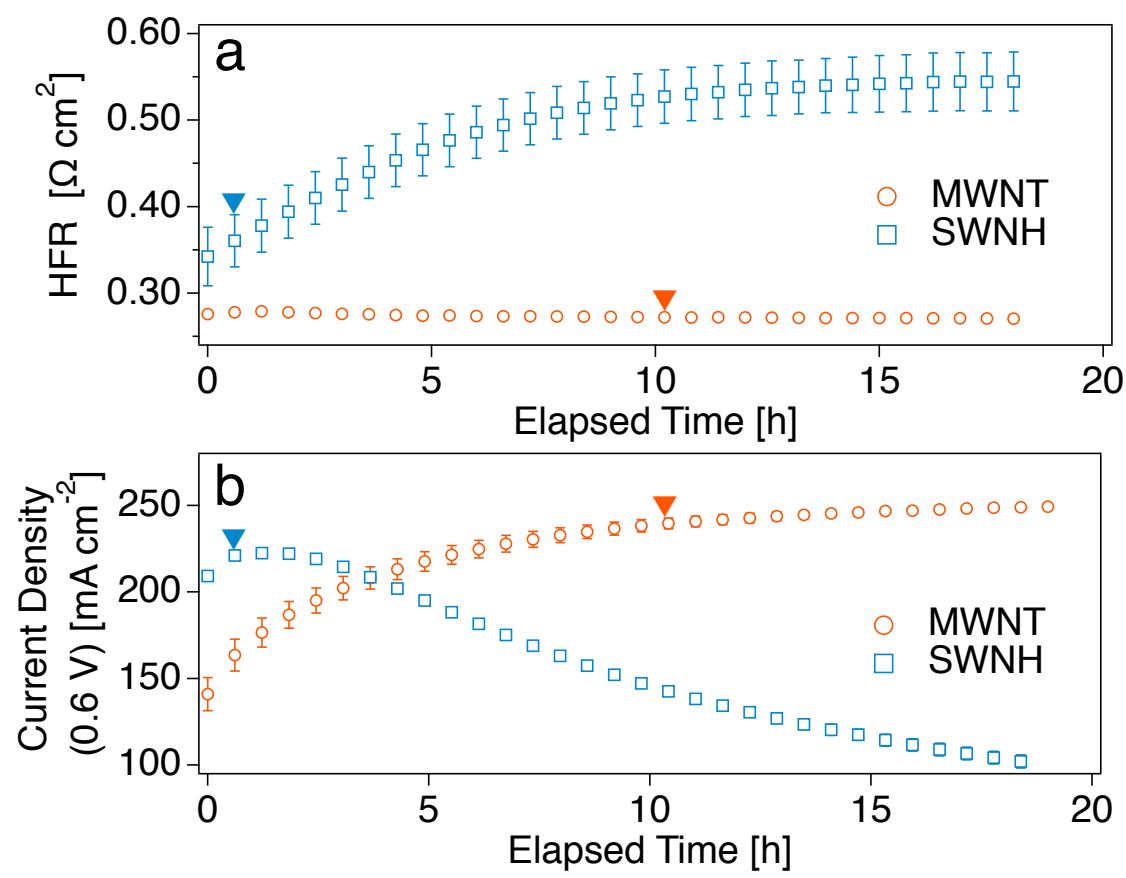

Figure 6: (a) Average high-frequency resistance (HFR) and (b) average current density at 0.6 $\mathrm{V}$ cell voltage for experimental SAFC cathodes recorded at $250{ }^{\circ} \mathrm{C}$ with $\mathrm{H}_{2}$ /air hydrated to $75{ }^{\circ} \mathrm{C}$ dew point. Triangular markers indicate the testing cycles selected for Figure 5

cell ohmic resistance (HFR). The observed HFR increase is likely to be caused by loss of carbon from the electrode, increasing interfacial contact resistance, a phenomenon that has also been observed in the case of PEMFCs[43, 44, 45]. Additionally, in the case of the experimental SAFCs cathodes, the carbon volume fraction is relatively low, and regions close to the CDP membrane could become completely devoid of percolating electronically-conductive domains via corrosion. This would effectively increase the spatial extent of the ionic conductor and increase the ohmic resistance of the cell. Furthermore, loss of carbon proximate to the $\mathrm{Pt}$ catalyst could result in physical detachment of the catalyst from the electronic transport network, again effectively reducing the electrochemically active surface area in the electrode. In the case of the SWNH cell, the inverse correlation of current density and HFR here is not surprising, given 
the impact of ohmic losses of the polarization curve at higher cell currents. Based on these results we conjectured that carbon corrosion was dominant in the loss of performance of the SWNH cell.

To test this hypothesis, we subjected fresh experimental cathodes at their peak performance to an accelerated corrosion test, holding the cell potential at $1.0 \mathrm{~V}$ with the cathode in a humidifed inert atmosphere $\left(\mathrm{N}_{2}\right.$ at $75{ }^{\circ} \mathrm{C}$ dew point $)$ with the anode under standard conditions $\left(\mathrm{H}_{2}\right.$ at $75{ }^{\circ} \mathrm{C}$ dew point). Voltage has been explored previously as an accelerant of the carbon corrosion reaction in both phosphoric acid $[9,10,11,12,13]$ and polymer-electrolyte[14, 46, 22, 19$]$ environments. The current resulting from the $1800 \mathrm{~s}$ potentiostatic hold are shown in Figure 7. We note a roughly linear current response in the log-log representation for short times, in good agreement with other investigations[11, $9,13,12]$. At longer times, there is a pronounced drop-off in the current from the SWNH electrode, possibly indicating that all of the electrochemically active carbon in the electrode has been consumed. Integrating the curves yields the charge passed, which we find to be $10 \times$ larger in the case of the SWNH electrode (15.2 C vs. $1.46 \mathrm{C})$. For a $100 \%$ efficient 4-electron oxidation of carbon to carbon dixoide, this is equivalent to approximately $37 \%$ of the total carbon in the cathode at the start of the test. Given that $100 \%$ coulombic efficiency for $\mathrm{CO}_{2}$ formation is unlikely (due to the formation of surface oxides[9]) we treat this value as an upper bound. In an identical $1.0 \mathrm{~V}$ test of a state-of-the-art carbonfree SAFC cathode[6], we also find oxidation currents of approximately $1.5 \mathrm{~mA}$ $\mathrm{mg}_{P t}^{-1}$ at $1.0 \mathrm{~V}$, but no appreciable change in cell performance or resistance after 1800 s (see Supplementary Information). This indicates that currents attributable to oxidation of $\mathrm{Pt}$ and of any current collector materials, in addition to carbon oxidation, can be observed via this method and further bounds the carbon consumption during the test.

Previous work in liquid acid environments identified a positive correlation between the degree of carbon graphitization and its resistance to corrosion[11, $47,17,19]$. Other guidelines for corrosion resistance were inferred from an extensive statistical analysis and included lower surface area, low roughness, 


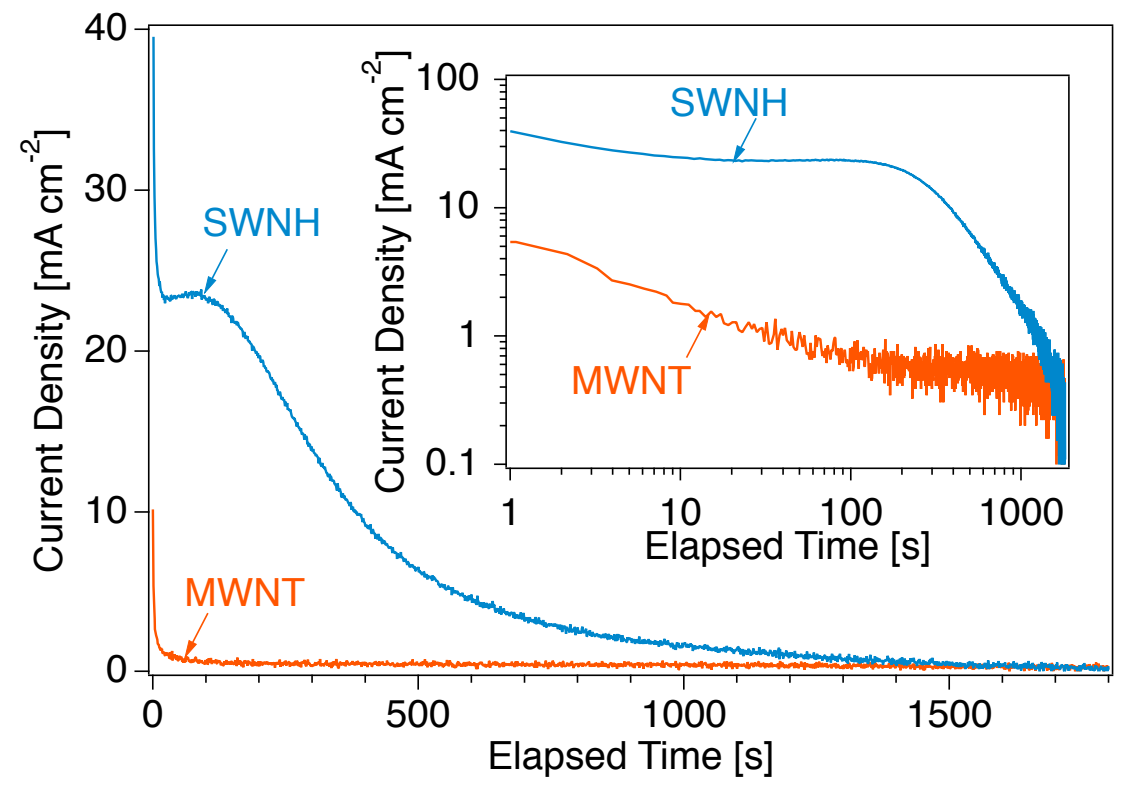

Figure 7: Chronoamperometric response from experimental cathodes held at $1.0 \mathrm{~V}$ in humidified $\mathrm{N}_{2}$. Cell temperature was $250{ }^{\circ} \mathrm{C}$ with anodes under $\mathrm{H}_{2}$ and all gases hydrated to $75{ }^{\circ} \mathrm{C}$ dew point.

and low populations of surface oxides[48]. Amorphous domains and defect sites were suggested as being especially vulnerable to corrosion $[47,17,19]$.

Clearly there is some correspondence between these investigations and what we observe at $250{ }^{\circ} \mathrm{C}$ in SAFC cathodes, namely, that MWNT supports are significantly more stable than SWNHs. We observe enhancement in SWNH Dband intensity via Raman spectroscopy (Figure 3) which has been previously been attributed to sp3-bonded[49], that is, non-graphitic carbon in SWNH aggregates. SWNHs also boast enhanced surface area with respect to the MWNT samples $\left(540 \mathrm{~m}^{2} \mathrm{~g}^{-1}\right.$ vs. $\left.155 \mathrm{~m}^{2} \mathrm{~g}^{-1}\right)$. However we must note that in our solid-state electrodes, the amount of electrochemically active carbon is essentially unknown, in stark contrast with the liquid cell approach used in earlier work, in which it is assumed that all of the carbon present is active. Given this categorical difference, the enhanced mixing of CDP with the SWNHs (Figure 4) 
may also contribute to an enhanced corrosion current.

A second key point must be made regarding the differences between $\mathrm{CsH}_{2} \mathrm{PO}_{4}{ }^{-}$ based cells and PEMFCs or PAFCs. These technologies are particularly affected by carbon corrosion during start-up events, when high voltages can result due to nonuniform fuel distribution in the stack[50]. SAFCs are inherently protected from this effect due to the low proton conductivity of CDP at temperatures below $230{ }^{\circ} \mathrm{C}$.

Electron micrographs of sectioned cells recovered after completion of the standard testing protocol suggest loss of carbon under normal (non-accelerated) conditions. Large areas of the post-test SWNH electrode are observed with no carbon visible, which we confirm also via TEM (see Supplementary Information). In contrast, we note no gross changes to the apparent carbon volume fraction in the case of the MWNT electrode. However we do note in this case an evolution in the CDP morphology towards larger primary particles and, in some areas, an apparent nanoscale mixing with the MWNT supports. This "wicking" of the CDP electrolyte into the Pt/MWNT bundles could occur due to formation of the liquid-like intermediate phase of $\mathrm{CDP}[51,52]$ and may explain the pronounced increase in performance over the course of the initial testing cycles, and continuation of this process could impact cell stability over longer timescales.

In both experimental electrodes we note significant coarsening in the $\mathrm{Pt}$ particle size to a minimum of $10 \mathrm{~nm}$ (see Supplementary Information), in a similar range to $\mathrm{Pt}$ recovered from state-of-the-art SAFC cathodes containing no carbon $[6,7]$. It is likely that here, as in our previous work, that particle coalescence is a primary coarsening channel due to the high metal loadings (60 wt\%) and the attendant initial particle clustering that we observed in the pristine samples (Figure 2).

An additional experimental cell with a MWNT-based cathode was operated for approximately 140 additional hours after completion of the standard cyclic protocol. The cell was held at a temperature of $250{ }^{\circ} \mathrm{C}$ and a constant voltage of $0.6 \mathrm{~V}$ with gases hydrated to a $65^{\circ} \mathrm{C}$ dew point (see Supplementary Informa- 

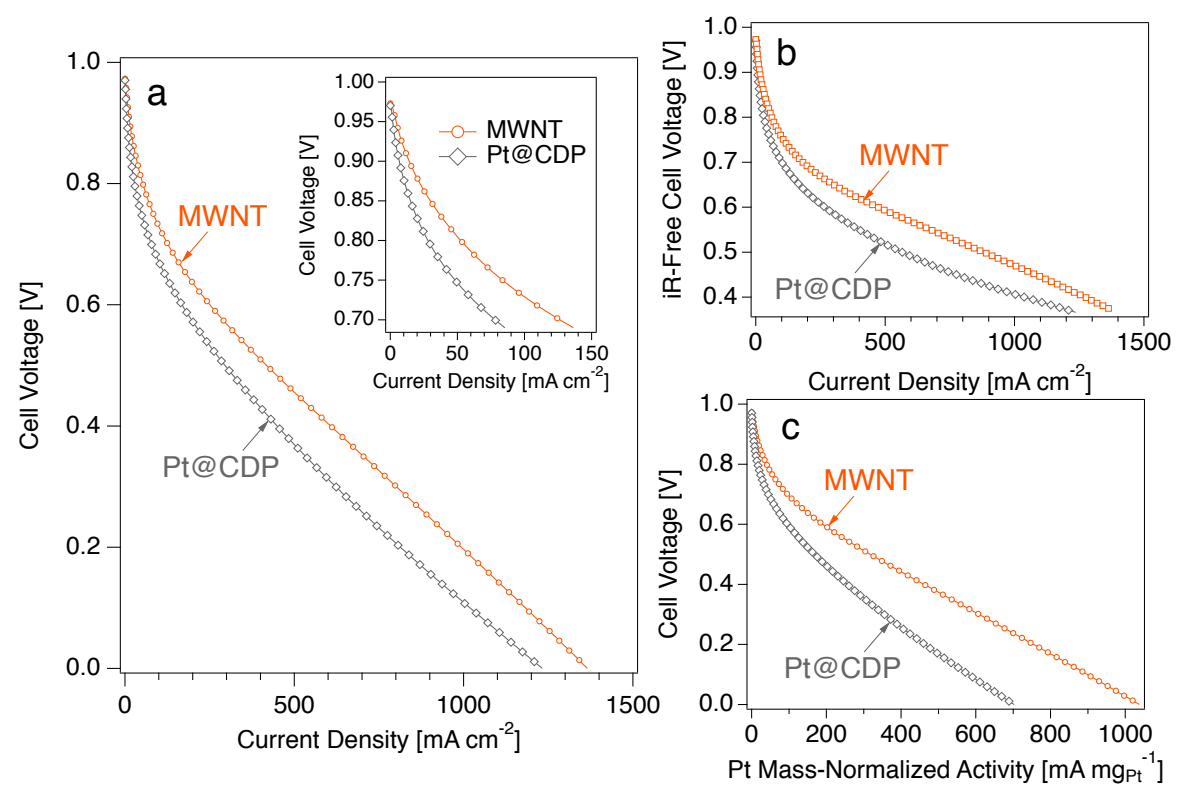

Figure 8: (a) Uncorrected (b) iR-free and (c) Pt mass-normalized SAFC polarization curves recorded at $250{ }^{\circ} \mathrm{C}$ with $\mathrm{H}_{2} /$ air at $75{ }^{\circ} \mathrm{C}$ dew point for MWNT-based cathode $\left(1.3 \mathrm{mg}_{\mathrm{Pt}}\right.$ $\left.\mathrm{cm}^{-2}\right)$ and state-of-the-art $20 \% \mathrm{Pt} @ \mathrm{CDP}$ cathode $\left(1.75 \mathrm{mg}_{\mathrm{Pt}} \mathrm{cm}^{-2}\right)$. Inset in (a) shows an enlargement of the kinetic region.

tion). Over 164 hours, the cell lost approximately $8 \%$ of its maximum current (from $243 \mathrm{~mA} \mathrm{~cm}^{-2}$ to $223 \mathrm{~mA} \mathrm{~cm}^{-2}$ ). This current degradation includes the effects of Pt particle coalesence in the cathode and any structural effects related to sintering of CDP domains in either electrode as well as the impact of support corrosion.

Given the stability of the MWNT cathodes, we prepared a state-of-the-art (carbon-free) SAFC cathode following our previously published procedures[6] with cathode $\mathrm{Pt}$ loading of $1.75 \mathrm{mg}_{\mathrm{Pt}} \mathrm{cm}^{-2}$. Polarization curves for the baseline cathode and the experimental MWNT cathode are compared in multiple representations in Figure 8. By any metric, the MWNT electrode exhibits enhanced performance with respect to the baseline electrode. We find an enhancement in current density of nearly $100 \%\left(52 \mathrm{~mA} \mathrm{~cm}^{-1}\right.$ vs. $\left.28 \mathrm{~mA} \mathrm{~cm}^{-1}\right)$ at $0.8 \mathrm{~V}$ (Figure $8 \mathrm{a}$, inset) and a striking disparity when activity is normalized to the mass 
of $\mathrm{Pt}$ in the cathode $\left(40 \mathrm{~mA} \mathrm{mg}_{\mathrm{Pt}}^{-1}\right.$ vs. $\left.16 \mathrm{~mA} \mathrm{mg}_{\mathrm{Pt}}^{-1}\right)$, as shown in Figure 8c. The experimental MWNT cell also exhibits a 31\% increase in maximum power density with respect to the baseline cell $\left(246 \mathrm{~mW} \mathrm{~cm}^{-2}\right.$ vs. $187 \mathrm{~mW} \mathrm{~cm}^{-2}$; see Supplementary Information). However we do also note again the contrast with the polarization response of the MWNT electrode in the apparent absence of mass-transport limitations in the case of the Pt@CDP baseline electrode, stemming from its macroporous structure.

\section{Conclusions}

Nanostructured fullerenic carbons comprising single-walled carbon nanohorns and multi-walled carbon nanotubes display vastly different properties as cathode catalyst supports in solid-state intermediate-temperature fuel cells based on the $\mathrm{CsH}_{2} \mathrm{PO}_{4}$ electrolyte. SWNHs synthesized by pulsed laser vaporization lead to well-dispersed, highly active electrodes with poor voltage stability due to a predisposition to electrochemical carbon corrosion. MWNT-based cathodes require a relatively lengthy activation period during which electrode activity increases considerably, eventually reaching near-parity with the SWNH-based formulation. The greater observed voltage stability of MWNT supports is attributable to a lower defect density and more graphitic character than SWNHs. Either formulation is capable of exceeding state-of-the-art SAFC cathode activity while containing $25 \%$ less Pt catalyst. Given their combination of activity and stability in SAFC cathodes, it is likely that MWNTs can be viable catalyst support in intermediate-temperature solid-state electrochemical devices operating at temperatures of at least $250^{\circ} \mathrm{C}$.

\section{Acknowledgements}

This work is supported by ARPA-E under Cooperative Agreement Number DE-AR0000499. SWNH synthesis and Raman spectroscopy were conducted at the Center for Nanophase Materials Sciences, a Department of Energy Office 
of Science User Facility. We thank Beth Armstrong for assistance with surface area measurements.

\section{References}

[1] S. Haile, C. Chisholm, K. Sasaki, D. Boysen, T. Uda, Faraday Discuss. 134 (2007) 17.

[2] D. Boysen, T. Uda, C. Chisholm, S. Haile, Science (80-. ). 303 (2004) 68.

[3] C. R. I. Chisholm, D. A. Boysen, A. B. Papandrew, S. K. Zecevic, S. Cha, K. A. Sasaki, Á. Varga, K. P. Giapis, S. Haile, Electrochem. Soc. Interface 18 (2009) 53-59.

[4] A. B. Papandrew, D. L. Wilson, N. M. Cantillo, S. Hawks, R. W. Atkinson, G. A. Goenaga, T. A. Zawodzinski, J. Electrochem. Soc. 161 (2014) F679F685.

[5] A. B. Papandrew, R. W. Atkinson III, R. R. Unocic, T. a. Zawodzinski, J. Mater. Chem. A 3 (2015) 3984-3987.

[6] A. B. Papandrew, C. R. Chisholm, R. A. Elgammal, M. M. Ozer, S. K. Zecevic, Chem. Mater. 23 (2011) 1659-1667.

[7] A. B. Papandrew, C. R. I. Chisholm, S. K. Zecevic, G. M. Veith, T. A. Zawodzinski, J. Electrochem. Soc. 160 (2013) F175-F182.

[8] W. Vielstich, A. Lamm, H. A. Gasteiger, Handbook of Fuel Cells: Fundamentals, Technology, Applications, 4 Volume Set, Wiley, 2003.

[9] K. Kinoshita, J. Bett, Carbon N. Y. 11 (1973) 237-247.

[10] J. McBreen, H. Olender, S. Srinivasan, K. V. Kordesch, J. Appl. Electrochem. 11 (1981) 787-796.

[11] P. Stonehart, Carbon N. Y. 22 (1984) 423-431. 
[12] P. Antonucci, F. Romeo, M. Minutoli, E. Alderucci, N. Giordano, Carbon N. Y. 26 (1988) 197-203.

[13] E. Passalacqua, P. Antonucci, M. Vivaldi, a. Patti, V. Antonucci, N. Giordano, K. Kinoshita, Electrochim. Acta 37 (1992) 2725-2730.

[14] L. M. Roen, C. H. Paik, T. D. Jarvi, Electrochem. Solid-State Lett. 7 (2004) A19.

[15] S. Maass, F. Finsterwalder, G. Frank, R. Hartmann, C. Merten, J. Power Sources 176 (2008) 444-451.

[16] H.-S. Oh, J.-H. Lee, H. Kim, Int. J. Hydrogen Energy 37 (2012) 1084410849.

[17] O. V. Cherstiouk, A. N. Simonov, N. S. Moseva, S. V. Cherepanova, P. A. Simonov, V. I. Zaikovskii, E. R. Savinova, Electrochim. Acta 55 (2010) 8453-8460.

[18] L. Castanheira, L. Dubau, M. Mermoux, G. Berthome, N. Caque, E. Rossinot, M. Chatenet, F. Maillard, ACS Catal. 4 (2014) 2258-2267.

[19] L. Castanheira, W. O. Silva, F. H. B. Lima, A. Crisci, L. Dubau, F. Maillard, ACS Catal. 5 (2015) 2184-2194.

[20] X. WANG, W. LI, Z. CHEN, M. WAJE, Y. YAN, J. Power Sources 158 (2006) 154-159.

[21] K. Lee, J. Zhang, H. Wang, D. P. Wilkinson, J. Appl. Electrochem. 36 (2006) 507-522.

[22] R. Borup, J. Meyers, B. Pivovar, Y. S. Kim, R. Mukundan, N. Garland, D. Myers, M. Wilson, F. Garzon, D. Wood, P. Zelenay, K. More, K. Stroh, T. Zawodzinski, J. Boncella, J. E. McGrath, M. Inaba, K. Miyatake, M. Hori, K. Ota, Z. Ogumi, S. Miyata, A. Nishikata, Z. Siroma, Y. Uchimoto, K. Yasuda, K.-I. Kimijima, N. Iwashita, Chem. Rev. 107 (2007) 3904-3951. 
[23] J. Tang, K. Jensen, M. Waje, W. Li, P. Larsen, K, J. Phys. Chem. (2007) 6-9.

[24] M. Lebert, M. Kaempgen, M. Soehn, T. Wirth, S. Roth, N. Nicoloso, Catal. Today 143 (2009) 64-68.

[25] E. Antolini, Appl. Catal. B Environ. 88 (2009) 1-24.

[26] Y. Shao, J. Liu, Y. Wang, Y. Lin, J. Mater. Chem. 19 (2009) 46.

[27] M. Boaventura, L. Brandao, a. Mendes, J. Electrochem. Soc. 158 (2011) B394.

[28] L. Brandão, C. Passeira, D. Mirabile Gattia, A. Mendes, J. Mater. Sci. 46 (2011) 7198-7205.

[29] M. Boaventura, L. Brandao, A. Mendes, J. Electrochem. Soc. 158 (2011) B394.

[30] Y. Qiao, C. M. Li, J. Mater. Chem. 21 (2011) 4027.

[31] Á. Varga, N. A. Brunelli, M. W. Louie, K. P. Giapis, S. M. Haile, J. Mater. Chem. 20 (2010) 6309.

[32] Á. Varga, M. Pfohl, N. A. Brunelli, M. Schreier, K. P. Giapis, S. M. Haile, Phys. Chem. Chem. Phys. 15 (2013) 15470-6.

[33] V. S. Thoi, R. E. Usiskin, S. M. Haile, Chem. Sci. 6 (2015) 1570-1577.

[34] A. A. Puretzky, D. B. Geohegan, X. Fan, S. J. Pennycook, Appl. Phys. A Mater. Sci. Process. 70 (2000) 153-160.

[35] A. A. Puretzky, D. J. Styers-Barnett, C. M. Rouleau, H. Hu, B. Zhao, I. N. Ivanov, D. B. Geohegan, Appl. Phys. a-Materials Sci. Process. 93 (2008) 849-855.

[36] Y. Liu, C. M. Brown, D. a. Neumann, D. B. Geohegan, A. a. Puretzky, C. M. Rouleau, H. Hu, D. Styers-Barnett, P. O. Krasnov, B. I. Yakobson, Carbon N. Y. 50 (2012) 4953-4964. 
[37] S. St. John, R. W. Atkinson, R. R. Unocic, T. A. Zawodzinski, A. B. Papandrew, J. Phys. Chem. C 119 (2015) 13481-13487.

[38] S. Bandow, F. Kokai, K. Takahashi, M. Yudasaka, L. Qin, S. Iijima, Chem. Phys. Lett. 321 (2000) 514-519.

[39] Y. Saito, T. Yoshikawa, S. Bandow, M. Tomita, T. Hayashi, Phys. Rev. B 48 (1993) 1907-1909.

[40] E. Bekyarova, K. Murata, M. Yudasaka, D. Kasuya, S. Iijima, H. Tanaka, H. Kahoh, K. Kaneko, J. Phys. Chem. B 107 (2003) 4681-4684.

[41] R. V. Hull, L. Li, Y. Xing, C. C. Chusuei, Chem. Mater. 18 (2006) 17801788 .

[42] R. A. DiLeo, B. J. Landi, R. P. Raffaelle, J. Appl. Phys. 101 (2007) 1-6.

[43] A. P. Young, J. Stumper, E. Gyenge, J. Electrochem. Soc. 156 (2009) B913.

[44] H.-S. Oh, K. H. Lim, B. Roh, I. Hwang, H. Kim, Electrochim. Acta 54 (2009) 6515-6521.

[45] Y.-C. Park, K. Kakinuma, M. Uchida, D. A. Tryk, T. Kamino, H. Uchida, M. Watanabe, Electrochim. Acta 91 (2013) 195-207.

[46] R. M. Darling, J. P. Meyers, J. Electrochem. Soc. 150 (2003) A1523.

[47] O. V. Cherstiouk, V. L. Kuznetsov, A. N. Simonov, I. N. Mazov, K. V. Elumeeva, N. S. Moseva, Phys. Status Solidi Basic Res. 247 (2010) $2738-$ 2742 .

[48] K. Artyushkova, S. Pylypenko, M. Dowlapalli, P. Atanassov, J. Power Sources 214 (2012) 303-313.

[49] S. Utsumi, H. Honda, Y. Hattori, H. Kanoh, K. Takahashi, H. Sakai, M. Abe, M. Yudasaka, S. Iijima, K. Kaneko, J. Phys. Chem. C 111 (2007) $5572-5575$. 
433

[50] C. a. Reiser, L. Bregoli, T. W. Patterson, J. S. Yi, J. D. Yang, M. L. Perry, T. D. Jarvi, Electrochem. Solid-State Lett. 8 (2005) A273.

[51] Y.-k. Taninouchi, T. Uda, Y. Awakura, A. Ikeda, S. Haile, J. Mater. Chem. 17 (2007) 3182.

[52] Y.-k. Taninouchi, T. Uda, Y. Awakura, Solid State Ionics 178 (2008) 16481653. 